\title{
ACTIVE INGREDIENTS COMBINATIONS FOR PATHOGENS AND PESTS CONTROL ON EGGPLANT CROPS IN THE FIELD
}

\author{
M.A. Buzatu ${ }^{1 *}$, G. Sbîrciog ${ }^{2}$, S. Cristea ${ }^{3}$ and M. Costache ${ }^{2}$ \\ 1 Engineering and Management of Vegetal and Animal Resources Doctoral School, \\ UASVM Bucharest, 59 Marasti Blvd, District 1, Bucharest, Romania. \\ ${ }^{2}$ Research and Development Institute for Vegetable and Flower Growing Vidra, 22 \\ Calea București Street, Vidra, Ilfov, Romania. \\ ${ }^{3}$ Department of Plant Pathology, University of Agronomic Sciences and Veterinary \\ Medicine of Bucharest, 59 Marasti Blvd, District 1, Bucharest, Romania. \\ * Corresponding author, e-mail: buzatumihaelaalina@yahoo.com
}

\section{ABSTRACT}

The present study aims to identify combinations of active substances for the complex control of pathogens and pests on eggplant crops in the field. The experiments were conducted between 2016 - 2017, in field conditions, using the variety of eggplant Luiza and the following experimental variants: V 1 - Acrobat MZ 69 WG 0.2\% + Mospilan 20 SG 0.04\%; V 2 - Acrobat MZ 69 WG 0.2\% + Vertimec 1.8 EC 0.1\%; V 3 - Acrobat MZ 69 WG 0.2\% + Laser 240 SC 0.05\%; V 4 - Melody Compact 49 WG 0.2\% + Mospilan 20 SG 0.04\%; V 5 - Melody Compact 49 WG 0.2\% + Vertimec 1.8 EC 0.1\%; V 6 - Melody Compact 49 WG 0.2\% + Laser 240 SC 0.05\%; V 7 - Ortiva Top 0.1\% + Mospilan 20 SG 0.04\%; V 8 - Ortiva Top 0.1\% + Vertimec 1.8 EC 0.1\%; V 9 Ortiva Top $0.1 \%$ + Laser 240 SC $0.05 \%$; V 10 - untreated control. The average efficacy of the treatment variants experienced in 2016 and 2017 varied between $83.2 \%$ (V4) and $85.0 \%$ (V8) depending on the combinations of products pathogens and pests control. Analyzing the yields obtained (34.6 -44.0 t / ha in 2016 and $33.5-43.1 \mathrm{t} / \mathrm{ha}$ in 2017), compared to the untreated control variant (30.4 t / ha in 2016 and $31.1 \mathrm{t} /$ ha in 2017), it is found that the yield differences obtained in addition to the untreated control variants were in all cases, very significant.

Keywords: early blight, gray mold, fruit rot, Colorado potato beetle, the common red spider, green nightshade lice, fruit caterpillar

\section{INTRODUCTION}

Eggplants (Solanum melongena L.) are among the most cultivated vegetable species worldwide, including in Romania. According to statistical data provided by FAO (2020), the area cultivated with eggplant in Romania was in 2018 of 9025 ha, and the total yield of 152719 tons. Eggplants are attacked by numerous pathogens and pests (Costache M., Roman T., 2007) of which we mention Alternaria porri f.sp.solani (early blight), Botrytiscinerea (gray mold), Phytophthora parasitica (fruit rot; Buzatu et. al., 2017) and Leptinotarsa decemlineata (Colorado beetle), Macrosiphum euphorbiae (green nightshade lice), Tetranychus urticae (the common red spider) and Helicoverpa armigera (fruit caterpillar). Alternaria porri f. sp. solani occur frequently in eggplant crops, especially in 
years with high average temperatures and heavy rainfall. Disease symptoms are characteristic dark brown to black lesions with concentric rings, which produce a 'target spot' effect (Cristea, 2005). Botrytis cinerea occurs frequently in crops of eggplants in protected areas, but also in the fields in years with abundant precipitation or if the culture is irrigated by sprinkling irrigation. On fruits, at different stages of development, the attack usually begins at the site of insertion of the peduncle and from here progresses to their tip. The attacked tissues discolor and turn purple, with a gray tinge. Phytophthora parasitica usually attacks mature fruits in the basal part that touch the ground or are close to it. On their surface appear large, brown spots, concentrically zoned, bordered by an obvious area of lighter color. Although the whole plant may be susceptible, fruit rot is the main symptom caused by Phytophthora parasitica in eggplants (Roberts \& al., 2008). Leptinotarsa decemlineata (Colorado potato beetle) attacks in the larval and adult stages, affecting all the aerial organs of the plants, with preferential location on the foliage. The common red spider (Tetranychus urticae) affects all the aerial organs of the plants and preferably the foliar leaves, being located on the lower part. Hossain et al. (2006) and Naher (2005) observed that by applying acaricides, the population of T. urticae in the field was drastically reduced. Sayed et al. (2006) found that Vertimec is more effective than Actellic and Biofly against $T$. urticae. Macrosiphum euphorbiae (green nightshade lice) is common in dry and hot years, forming colonies clustered on the underside of leaves and scattered on flowers. The young larvae of Helicoverpa armigera (fruit caterpillar) develop on leaves and flowers, after which they enter into the fruit where they consume the seeds and leave numerous droppings. The attacked fruits become unfit for consumption.

The experiments organized at R.I.V.F.G Vidra aimed to prevent the occurrence and control of the attack of pathogens and pests in the crop of eggplant by using combinations of active substances.

\section{MATERIALS AND METHODS}

The experiments were carried out in 2016 and 2017, in field conditions, using the Luiza eggplant variety. The products used to control pathogens and pests in eggplant field crops are shown in table 1.

Table 1. Products used for pathogens and pests control of eggplant crop in the field

(Vidra, 2016 - 2017)

\begin{tabular}{|c|c|c|c|}
\hline $\begin{array}{l}\text { Product and } \\
\text { concentration }\end{array}$ & Active ingredients & Mode of action & $\begin{array}{c}\text { Break } \\
\text { time } \\
\text { (days) }\end{array}$ \\
\hline \multicolumn{4}{|l|}{ Fungicides } \\
\hline Acrobat MZ 69WG 0,2\% & $\begin{array}{l}\text { dimethomorph } 9 \%+\text { mancozeb } \\
60 \%\end{array}$ & $\begin{array}{l}\text { translaminar, local } \\
\text { systemic + contact }\end{array}$ & 7 \\
\hline $\begin{array}{l}\text { Melody Compact } 49 \text { WG } \\
0,2 \%\end{array}$ & $\begin{array}{l}\text { iprovalicarb } 8.4 \%+\mathrm{Cu} \text { as } \\
\text { oxychloride } \mathrm{Cu} 40.6 \%\end{array}$ & systemic, contact & 7 \\
\hline Ortiva Top $0,1 \%$ & $\begin{array}{lllll}\text { azoxystrobin } 200 \mathrm{~g} / & \mathrm{l} & + \\
\text { diphenoconazole } 125 \mathrm{~g} / \mathrm{l} & & \\
\end{array}$ & $\begin{array}{c}\text { contact, local systemic, } \\
\text { translaminar }\end{array}$ & 7 \\
\hline \multicolumn{4}{|l|}{ Insecticides - acaricides } \\
\hline Mospilan 20 SG 0,04 \% & acetamiprid $20 \%$ & systemic & 3 \\
\hline Vertimec 1,8 EC $0,1 \%$ & abamectin $18 \mathrm{~g} / \mathrm{l}$ & $\begin{array}{l}\text { systemic, translaminar, } \\
\text { penetrating, ingestion }\end{array}$ & 3 \\
\hline Laser 240 SC 0,05 \% & spinosad $240 \mathrm{~g} / \mathrm{l}$ & contact, ingestion & 3 \\
\hline
\end{tabular}


The organized experience was of a single-factor type, placed in randomized blocks, with 10 variants, in 3 replications. The crop was established on May 16, 2016 and on May 12, 2017, on land mulched with black polyethylene foil. The size of the repetition plot was $7.5 \mathrm{~m}^{2}$, having a number of 24 plants, arranged in 2 rows, $70 \mathrm{~cm}$ apart and $40 \mathrm{~cm}$ between plants on the row. The experimental variants were the following: V 1 - Acrobat MZ 69 WG $0.2 \%+$ Mospilan 20 SG 0.04\%; V 2 - Acrobat MZ 69 WG 0.2\% + Vertimec 1.8 EC 0.1\%; V 3 - Acrobat MZ 69 WG 0.2\% + Laser 240 SC 0.05\%; V 4 - Melody Compact 49 WG 0.2\% + Mospilan 20 SG 0.04\%; V 5 - Melody Compact 49 WG 0.2\% + Vertimec 1.8 EC 0.1\%; V 6 - Melody Compact 49 WG $0.2 \%$ + Laser 240 SC $0.05 \%$; V 7 - Ortiva Top 0.1\% + Mospilan 20 SG 0.04\%; V 8 - Ortiva Top 0.1\% + Vertimec 1.8 EC 0.1\%; V 9 - Ortiva Top 0.1\% + Laser 240 SC 0.05\%; V 10 untreated control.

The physical compatibility of the product mixtures was determined in the laboratory. Three treatments were performed during the growing season. The first treatment was done at the beginning of the risk of infection and infestation and the others at intervals of 7-10 days. During the vegetation period, observations were made regarding the occurrence and evolution of the attack of pathogens: frequency (\%) and severity (\%) of the attack and the degree of attack (\%) and efficacy (\%) were calculated. The degree of attack was calculated with the formula (F \% x S \%) / 100 and the efficacy with the formula (untreated DA\% treated DA\%) x 100 / untreated DA. Observations were also made on the yield, by weighing the fruits on variants and repetitions at harvest.

Yield data were statistically processed by analysis of variation (ANOVA), and the level of significance of yield differences was interpreted with the Fisher test: ${ }^{\circ \circ}=$ Non significant; ${ }^{\circ}$ =significant; ${ }^{*}$ = distinct significant; ${ }^{* * *}=$ very significant.

\section{RESULTS AND DISCUSSIONS}

In the experimental crops of eggplant in the field, the attack of the following pathogens and pests was manifested in 2016 and 2017: Alternaria porri f.sp. solani (early blight), Botrytis cinerea (gray mold), Phytophthora parasitica (fruit rot), Leptinotarsa

decemlineata (Colorado beetle), Macrosiphum euphorbiae (green nightshade lice), Tetranychus urticae (common red spider).

The combinations of products tested were noted for their good efficacy in controlling the following harmful organisms (Tables 2 and 3):

1. Acrobat MZ 69 WG + Mospilan 20 SG: for Alternaria porri f.sp. solani,Botrytis cinerea, Phytophthora parasitica, Leptinotarsa decemlineata and Macrosiphum euphorbiae (average $\mathrm{E}=83.6 \%$ - 2016; 83.4\% - 2017; 83.5\% - average value 2016-2017);

2. Acrobat MZ $69 \mathrm{WG}+$ Vertimec 1.8 EC: for Alternaria porri f.sp. solani,Botrytis cinerea, Phytophthora parasitica and Tetranychus urticae (average E = 85.3\% - 2016; 84.4\% 2017; 84.8\% - average value 2016-2017);

3. Acrobat MZ 69 WG + Laser 240 SC: for Alternaria porri f.sp. solani,Botrytis cinerea, Phytophthora parasitica and Helicoverpa armigera (average E = 84.2\% - 2016; 84.2\% - 2017; 84.2\% - average value 2016-2017);

4. Melody Compact 49 WG + Mospilan 20 SG: for Alternaria porri f.sp. solani, Botrytis cinerea, Phytophthora parasitica, Leptinotarsa decemlineata and Macrosiphum euphorbiae (average $\mathrm{E}=83.1 \%$ - 2016; 83.4\% - 2017; 83.2\% - average value 2016-2017);

5. Melody Compact 49 WG + Vertimec 1.8 EC: for Alternaria porri f.sp. solani, Botrytis cinerea, Phytophthora parasitica and Tetranychus urticae (average E $=84.2 \%-2016 ; 84.37 \%$ - 2017; 84.2\% - average value years 2016-2017); 
6. Melody Compact 49 WG + Laser 240 SC: for Alternaria porri f.sp. solani, Botrytis cinerea, Phytophthora parasitica and Helicoverpa armigera (average E $=83.7 \%-2016$; 83.4\% - 2017; 83.5\% - average value 2016-2017);

7. Ortiva Top + Mospilan 20 SG: for Alternaria porri f.sp. solani, Botrytis cinerea, Phytophthora parasitica, Leptinotarsa decemlineata and Macrosiphum euphorbiae (average E = 83.7\% - 2016; 85.0\% - 2017; 84.35\% - average value 2016-2017);

8. Ortiva Top + Vertimec 1.8 EC: for Alternaria porri f.sp. solani, Botrytis cinerea, Phytophthora parasitica and Tetranychus urticae (average E $=85.5 \%-2016 ; 85.0 \%-2017$; 85.0\% - average value 2016-2017);

9. Ortiva Top + Laser 240 SC: for Alternaria porri f.sp. solani, Botrytis cinerea, Phytophthora parasitica and Helicoverpa armigera (average E = 84.1\% - 2016; 83.2\% - 2017; 83.6\% - average value 2016-2017);

The average efficacy of the treatment variants experienced in 2016 and 2017 varied between $83.2 \%$ (V4) and $85.0 \%$ (V8) depending on the combination of products pathogens and pest control.

Table 2. The efficacy of some combinations of fungicides with insecticides - acaricides in controling of pathogens and pests in the eggplant crop in the field (Vidra, 2016)

\begin{tabular}{|c|c|c|c|c|c|c|c|c|c|c|c|c|c|c|c|}
\hline \multirow[t]{3}{*}{ Variant } & \multicolumn{14}{|c|}{ Pathogens and pests } & \multirow{3}{*}{$\begin{array}{c}\text { Average } \\
\text { efficacy } \\
(\%)^{*}\end{array}$} \\
\hline & \multicolumn{2}{|c|}{$\begin{array}{c}\text { Alternaria } \\
\text { porri f.sp } \\
\text { solani }\end{array}$} & \multicolumn{2}{|c|}{$\begin{array}{l}\text { Botryris } \\
\text { cinerea }\end{array}$} & \multicolumn{2}{|c|}{$\begin{array}{l}\text { Phytophthora } \\
\text { parasitica }\end{array}$} & \multicolumn{2}{|c|}{$\begin{array}{l}\text { Leptinotarsa } \\
\text { decemlineata }\end{array}$} & \multicolumn{2}{|c|}{$\begin{array}{c}\text { Macrosiphum } \\
\text { euphorbiae }\end{array}$} & \multicolumn{2}{|c|}{$\begin{array}{c}\text { Tetranychus } \\
\text { urticae }\end{array}$} & \multicolumn{2}{|c|}{$\begin{array}{c}\text { Helicoverpa } \\
\text { armigera }\end{array}$} & \\
\hline & $\begin{array}{l}\text { DA } \\
(\%)\end{array}$ & $\begin{array}{c}E \\
(\%) \\
\end{array}$ & $\begin{array}{l}\text { DA } \\
(\%)\end{array}$ & $\begin{array}{c}E \\
(\%)\end{array}$ & $\begin{array}{l}\text { DA } \\
(\%)\end{array}$ & $\begin{array}{c}E \\
(\%)\end{array}$ & $\begin{array}{l}\mathrm{DA} \\
(\%)\end{array}$ & $\begin{array}{c}E \\
(\%)\end{array}$ & $\begin{array}{c}\text { DA } \\
(\%)\end{array}$ & $\begin{array}{c}E \\
(\%)\end{array}$ & $\begin{array}{l}\text { DA } \\
(\%)\end{array}$ & $\begin{array}{c}E \\
(\%)\end{array}$ & $\begin{array}{c}\text { DA } \\
(\%)\end{array}$ & $\begin{array}{c}E \\
(\%)\end{array}$ & \\
\hline V1. & 2.0 & 85.8 & 2.3 & 79.5 & 1.5 & 88.2 & 2.0 & 79.2 & 1.3 & 85.4 & 4.1 & 49.4 & 3.6 & 63.3 & 83.6 \\
\hline V2. & 2.1 & 85.1 & 2.4 & 78.6 & 1.6 & 87.4 & 4.5 & 53.1 & 3.5 & 60.7 & 0.8 & 90.1 & 4.1 & 58.2 & 85.3 \\
\hline V3. & 2.3 & 83.7 & 2.6 & 76.8 & 1.3 & 89.8 & 4.7 & 54.0 & 3.0 & 66.3 & 4.5 & 44.4 & 1.3 & 86.7 & 84.2 \\
\hline V4. & 2.5 & 82.3 & 2.4 & 78.6 & 1.1 & 91.3 & 1.7 & 82.3 & 1.7 & 80.9 & 4.4 & 45.7 & 3.9 & 60.2 & 83.1 \\
\hline V5. & 2.7 & 80.8 & 2.6 & 76.8 & 1.4 & 89.0 & 4.8 & 50.0 & 3.8 & 57.3 & 0.8 & 90.1 & 4.2 & 57.1 & 84.2 \\
\hline V6. & 2.4 & 83.0 & 2.7 & 75.9 & 1.5 & 88.2 & 5.1 & 46.9 & 3.4 & $\begin{array}{ll}61.8 \\
\end{array}$ & 4.5 & 44.4 & 1.2 & 87.7 & 83.7 \\
\hline V7. & 2.2 & 84.4 & 1.5 & 86.6 & 2.1 & 83.5 & 1.9 & 80.2 & 1.5 & 83.1 & 3.9 & 51.8 & 3.7 & 62.2 & 83.7 \\
\hline V8. & 2.5 & 82.3 & 1.6 & 85.7 & 1.9 & 85.0 & 4.7 & 51.0 & 3.9 & $\begin{array}{l}56.2 \\
\end{array}$ & 0.9 & 88.9 & 4.4 & 55.1 & 85.5 \\
\hline V9. & 2.3 & 83.7 & 1.8 & 83.9 & 2.4 & 81.1 & 5.3 & 44.8 & 3.3 & 62.9 & 4.6 & 43.2 & 1.2 & 87.7 & 84.1 \\
\hline V10. & 14.1 & - & 11.2 & - & 12.7 & - & 9.6 & - & 8.9 & - & 8.1 & 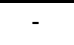 & 9.8 & - & - \\
\hline
\end{tabular}

* Only values above $75 \%$ were taken into account when calculating the average efficacy

Table 3. The efficacy of some combinations of fungicides with insecticides - acaricides in controling of pathogens and pests in the eggplant crop in the field (Vidra, 2017)

\begin{tabular}{|c|c|c|c|c|c|c|c|c|c|c|c|c|c|c|c|}
\hline \multirow[t]{3}{*}{ Variant } & \multicolumn{14}{|c|}{ Pathogens and pests } & \multirow{3}{*}{$\begin{array}{c}\text { Average } \\
\text { efficacy } \\
(\%)^{*}\end{array}$} \\
\hline & \multicolumn{2}{|c|}{$\begin{array}{l}\text { Alternaria } \\
\text { so lani } \\
\end{array}$} & \multicolumn{2}{|c|}{$\begin{array}{l}\text { Botryris } \\
\text { cinerea }\end{array}$} & \multicolumn{2}{|c|}{$\begin{array}{c}\text { Phytophthora } \\
\text { parasitica }\end{array}$} & \multicolumn{2}{|c|}{$\begin{array}{l}\text { Leptinotarsa } \\
\text { decemlineata }\end{array}$} & \multicolumn{2}{|c|}{$\begin{array}{c}\text { Macrosiphum } \\
\text { euphorbiae }\end{array}$} & \multicolumn{2}{|c|}{$\begin{array}{c}\text { Tetranychus } \\
\text { urticae }\end{array}$} & \multicolumn{2}{|c|}{$\begin{array}{c}\text { Helicoverpa } \\
\text { armigera }\end{array}$} & \\
\hline & $\begin{array}{l}\mathrm{GA} \\
(\%)\end{array}$ & $\begin{array}{l}\mathrm{E} \\
(\%)\end{array}$ & $\begin{array}{l}\text { FA } \\
(\%)\end{array}$ & $\begin{array}{l}\mathrm{E} \\
(\%)\end{array}$ & $\begin{array}{l}\text { FA } \\
(\%)\end{array}$ & $\begin{array}{l}E \\
(\%)\end{array}$ & $\begin{array}{l}\mathrm{GA} \\
(\%)\end{array}$ & $\begin{array}{l}E \\
(\%)\end{array}$ & $\begin{array}{l}\text { GA } \\
(\%)\end{array}$ & $\begin{array}{l}E \\
(\%)\end{array}$ & $\begin{array}{l}\mathrm{GA} \\
(\%)\end{array}$ & $\begin{array}{l}E \\
(\%)\end{array}$ & $\begin{array}{l}\text { FA } \\
(\%)\end{array}$ & $\begin{array}{l}E \\
(\%)\end{array}$ & \\
\hline V1. & 1.7 & 85.0 & 2.0 & 79.6 & 1.3 & 87.6 & 1.8 & 79.3 & 1.1 & 85.7 & 3.9 & 42.6 & 3.4 & 58.5 & 83.4 \\
\hline V2. & 1.9 & 84.8 & 2.2 & 77.5 & 1.5 & 85.7 & 4.2 & 51.7 & 3.2 & 58.4 & 0.7 & 89.7 & 4.0 & 51.2 & 84.4 \\
\hline V3. & 2.1 & 83.2 & 2.3 & 76.5 & 1.0 & 90.5 & 4.5 & 48.3 & 2.8 & 63.6 & 4.6 & 32.3 & 1.1 & 86.6 & 84.2 \\
\hline V4. & 2.2 & 82.4 & 2.2 & 77.5 & 0.8 & 92.4 & 1.5 & 82.7 & 1.4 & 81.8 & 4.2 & 38.2 & 3.7 & 54.9 & 83.4 \\
\hline V5. & 2.5 & 80.0 & 2.4 & 75.5 & 1.0 & 90.5 & 4.6 & 47.1 & 3.5 & 54.5 & 0.6 & 91.2 & 3.9 & 52.4 & 84.3 \\
\hline V6. & 2.3 & 81.6 & 2.4 & 75.5 & 1.2 & 88.6 & 4.8 & 44.8 & 3.0 & 61.0 & 4.3 & 36.8 & 1.0 & 87.8 & 83.4 \\
\hline V7. & 2.0 & 84.0 & 1.3 & 86.7 & 1.8 & 82.8 & 1.7 & 80.4 & 1.2 & 84.4 & 3.7 & 45.6 & 3.4 & 58.5 & 83.7 \\
\hline V8. & 2.3 & 81.6 & 1.3 & 86.7 & 1.6 & 84.8 & 4.4 & 49.4 & 3.7 & 51.9 & 0.9 & 86.8 & 4.1 & 50.0 & 85.0 \\
\hline V9. & 2.1 & 83.2 & 1.5 & 84.7 & 2.0 & 80.9 & 4.9 & 43.7 & 2.9 & 62.3 & 4.8 & 29.4 & 1.3 & 84.1 & 83.2 \\
\hline V10. & 12.5 & - & 9.8 & - & 10.5 & - & 8.7 & - & 7.7 & - & 6.8 & - & 8.2 & - & - \\
\hline
\end{tabular}

* Only values above $75 \%$ were taken into account when calculating the average efficacy 
In 2016, the yield obtained from the eggplant crop in the field were between $33.5 \mathrm{t} / \mathrm{ha} \mathrm{V}$ 1) and $43.1 \mathrm{t} / \mathrm{ha}(\mathrm{V} \mathrm{6}$ ), and for the untreated control variant it was $30.4 \mathrm{t} / \mathrm{ha}$ (table 4). The highest yields were obtained at variants 6 (43.1 t / ha; 141.8\%), 5 (38.9 t / ha; 127.9\%) and 4 (38.1 t / ha; $125,3 \%)$.

Table 4. Influence of treatments with different combinations of pesticides on the yield of eggplant in the field (Vidra, 2016)

\begin{tabular}{|c|c|c|c|c|c|}
\hline \multirow[t]{2}{*}{ Variant } & \multicolumn{4}{|c|}{ Yield } & \multirow[t]{2}{*}{ Significance } \\
\hline & $\mathrm{kg} / \mathrm{m}^{2}$ & t/ha & $\begin{array}{l}\% \text { compared to the } \\
\text { untreated control variant }\end{array}$ & $\begin{array}{l}\text { Difference from untreated } \\
\text { control variant }(\mathrm{t} / \mathrm{ha})\end{array}$ & \\
\hline V1. & 3.35 & 33.5 & 110.2 & +3.1 & *** \\
\hline V2. & 3.43 & 34.3 & 112.8 & +3.9 & $* * *$ \\
\hline V3. & 3.66 & 36.6 & 120.4 & +6.2 & $* * *$ \\
\hline V4. & 3.81 & 38.1 & 125.3 & +7.7 & $* * *$ \\
\hline V5. & 3.89 & 38.9 & 127.9 & +8.5 & $* * *$ \\
\hline V6. & 4.31 & 43.1 & 141.8 & +12.7 & $* * *$ \\
\hline V7. & 3.44 & 34.4 & 113.2 & +4.0 & $* * *$ \\
\hline V8. & 3.55 & 35.5 & 116.8 & +5.1 & $* * *$ \\
\hline V9. & 3.74 & 37.4 & 123.0 & +7.0 & $* * *$ \\
\hline V10. & 3.04 & 30.4 & - & - & - \\
\hline
\end{tabular}

$\operatorname{LSD}_{5 \%}=0.771 ; \operatorname{LSD}_{1 \%}=1.051 ; \operatorname{LSD}_{0.1 \%}=1.423$

In 2017 the yields obtained from the eggplant crop in the field were between $34.6 \mathrm{t} /$ ha (V 1) and $44.0 \mathrm{t} / \mathrm{ha}(\mathrm{V} \mathrm{6}$ ), and in the untreated control variant it was $31.1 \mathrm{t} /$ ha (table 5). The highest yields were obtained at variants 6 (44.0 t / ha; 141.5\%), 5 (39.8 t / ha; 128.0\%) and 4 (38.7 t / ha; $124.4 \%)$.

Table 5. The influence of treatments with different combinations of pesticides on the yield of eggplant in the field (Vidra, 2017)

\begin{tabular}{|c|c|c|c|c|c|}
\hline Variant & \multicolumn{3}{|c|}{ Yield } & Significance \\
\cline { 2 - 6 } & $\mathrm{kg} / \mathrm{m}^{2}$ & $\mathrm{t} / \mathrm{ha}$ & $\begin{array}{c}\text { \% compared to the } \\
\text { untreated control } \\
\text { variant }\end{array}$ & $\begin{array}{c}\text { Difference from untreated } \\
\text { control variant } \mathrm{t} / \mathrm{ha})\end{array}$ & \\
\hline 1. & 3.46 & 34.6 & 111.2 & +3.5 & $* * *$ \\
\hline 2. & 3.48 & 34.8 & 111.9 & +3.7 & $* * *$ \\
\hline 3. & 3.74 & 37.4 & 120.2 & +7.6 & $* * *$ \\
\hline 4. & 3.87 & 38.7 & 124.4 & +8.7 & $* * *$ \\
\hline 5. & 3.98 & 39.8 & 128.0 & +12.9 & $* * *$ \\
\hline 6. & 4.40 & 44.0 & 141.5 & +4.1 & $* * *$ \\
\hline 7. & 3.52 & 35.2 & 113.2 & +5.0 & $*$ \\
\hline 8. & 3.61 & 36.1 & 116.1 & +7.1 & $*$ \\
\hline 9. & 3.82 & 38.2 & 122.8 & - & $*$ \\
\hline 10. & 3.11 & 31.1 & - & & $*$ \\
\hline
\end{tabular}

$\operatorname{LSD}_{5 \%}=1.157 ; \operatorname{LSD}_{1 \%}=1.578 ;$ LSD $_{0.1 \%}=2.136$ 


\section{CONCLUSIONS}

- $\quad$ The application of three treatments with the combinations between Acrobat MZ 69 WG, Melody Compact 49 WG or Ortiva Top with Mospilan 20 SG ensured a good protection of the eggplant plants from the attack of harmful organisms like: Alternaria porri f.sp. solani, Botrytis cinerea, Phytophthora parasitica, Leptinotarsa decemlineata and Macrosiphum euphorbiae;

- $\quad$ The combinations between Acrobat MZ 69 WG, Melody Compact 49 WG or Ortiva Top with Vertimec 1.8 EC protected well the eggplant plants from the attack of pathogens of Alternaria porri f.sp. solani,Botrytis cinerea, Phytophthora parasitica and the pest Tetranychus urticae;

- $\quad$ The combinations between Acrobat MZ 69 WG, Melody Compact 49 WG or Ortiva Top with Laser 240 SC ensured a good protection of the eggplant plants from the attack of harmful organisms like Alternaria porri f.sp. solani, Botrytis cinerea, Phytophthora parasitica and Helicoverpa armigera;

- $\quad$ The best results in terms of yield were obtained in variants 6, 5 and 4 (V 6 - Melody Compact 49 WG $0.2 \%$ + Laser 240 SC $0.05-43.1 \mathrm{t} /$ ha in 2016 and $44 \mathrm{t} /$ ha in 2017; V 5 Melody Compact 49 WG 0.2\% + Vertimec 1.8 EC 0.1\% - $38.9 \mathrm{t} /$ ha in 2016 and $39.8 \mathrm{t} / \mathrm{ha}$ in 2017; V4 - Melody Compact 49 WG 0.2\% + Mospilan 20 SG 0.04\% - 38.1 t / ha in 2016 and $38.7 \mathrm{t}$ / ha in 2017).

- In variant 6, the yield had increased from $12.7 \mathrm{t}$ / ha in 2016 to $12.9 \mathrm{t}$ / ha in 2017; in variant 5 , the production had increased compared to the untreated control from $8.5 \mathrm{t} / \mathrm{ha}$ in 2016 to $8.7 \mathrm{t} / \mathrm{ha}$ in 2017 and in variant 4 the yield had increased compared to the untreated control from $7.7 \mathrm{t}$ / ha in 2016 and $7.6 \mathrm{t}$ / ha in 2017;

- We appreciate that the superior yield results obtained for these variants are due especially to the high efficacy of the fungicide Melody Compact 49 WG on the fungus Phytophthora parasitica (89.7\%, respectively 89.5 on average over the two years).

\section{REFERENCES}

1. Buzatu M.A., Costache M., Cristea S., 2017. Behavior of some eggplant cultivars (Solanum melongena L.) at the pathogens attack in greenhouse and field. Lucrări Ştiinţifice, USAMV Iași, vol. 60 (1), seria Agronomie, 117-122;

2. Costache M., Roman T., 2007. Bolile și dăunătorii culturilor de legume, Editura Agris - Redacția Revistelor Agricole, București;

3. Cristea S., 2005. Fitopatologie, vol. 2, Editura Cris Book Universal, București.

4. Food and Agriculture Organization of the United Nation. 2020.www.fao.org

5. Hossain S., Haque M.M., Naher N., 2006. Control of two- spotted spider mite Tetranychus urticae Koch (Acari: Tetranychidae) by some selected chemicals,Univ. J. Zool. RajshahiUniv., 25, pp. 15-18;

6. Naher, N., 2005. Integrated management of two-spotted spider mite infesting beans.(Unpubl.Ph.D. thesis). Institute of Biological Science, Rajshahi University, p. 221.

7. Sayed M.A., Rahil A.A.R., M. Abdel, Abd-El-Gayed A.A., 2006. Latent effect of Actellic, Vertimec and Biofly against Bemisia tabaci and Tetranychus urticae and its side effect to thepredators Stethours gilvifrons and Euseius scutalis, Egypt. J. Appl. Sci., 21 (2B), pp. 670-680

8. Roberts, P. \& McGovern, Robert \& Kucharek, T. \& Mitchell, D., 2008. Vegetable Diseases Caused by Phytophthora capsici in Florida. University of Florida-IFAS, Cooperative Extension Service. SP159. 1-6. 